\title{
Holocene climate conditions in central Yakutia (Eastern Siberia) inferred from sediment composition and fossil chironomids of Lake Temje
}

\author{
Larisa Nazarova $^{\mathrm{a}, \mathrm{b}, *}$, Herman Lüpfert $^{\mathrm{a}}$, Dmitry Subetto ${ }^{\mathrm{c}}$, Ludmila Pestryakova ${ }^{\mathrm{d}}$, Bernhard Diekmann ${ }^{\mathrm{a}}$ \\ ${ }^{a}$ Alfred Wegener Institute for Polar and Marine Research, Research Unit Potsdam, Telegrafenberg A43, 14473 Potsdam, Germany \\ ${ }^{\mathrm{b}}$ Kazan Federal University, Kremlyovskaya Street 18, 420018 Kazan, Russia \\ ${ }^{\text {' } S t . ~ P e t e r s b u r g ~ G e r z e n ~ P e d a g o g i c a l ~ U n i v e r s i t y, ~ M o i k a ~ 48, ~} 191186$ St. Petersburg, Russia \\ ${ }^{\mathrm{d}}$ North-Eastern Federal University, 58 Belinsky Street, Yakutsk 677891, Russia
}

\section{A R T I C L E I N F O}

\section{Article history:}

Available online 14 November 2012

\begin{abstract}
A B S T R A C T
A $380 \mathrm{~cm}$ long sediment core from Lake Temje (central Yakutia, Eastern Siberia) was studied to infer Holocene palaeoenvironmental change in the extreme periglacial setting of eastern Siberia during the last 10,000 years. Data on sediment composition were used to characterize changes in the depositional environment during the ontogenetic development of the Lake Temje. The analysis of fossil chironomid remains and statistical treatment of chironomid data by the application of a newly developed regional Russian transfer functions provided inferences of mean July air temperatures ( $T_{\text {July }}$ ) and water depths (WD). Reconstructed WDs show minor changes throughout the core and range between 80 and $120 \mathrm{~cm}$. All the fluctuations in reconstructed water depth lie within the mean error of prediction of the inference model (RMSEP $=0.35$ ) so it is not possible to draw conclusions from the reconstructions. A qualitative and quantitative reconstruction of Holocene climate in central Yakutia recognized three stages of palaeoenvironmental changes. The early Holocene between 10 and $8 \mathrm{ka}$ BP was characterized by colderthan-today and moist summer conditions. Cryotextures in the lake sediments document full freezing of the lake water during the winter time. A general warming trend started around $8.0 \mathrm{ka}$ BP in concert with enhanced biological productivity. Reconstructed mean $T_{\text {July }}$ were equal or up to $1.5^{\circ} \mathrm{C}$ higher than today between $6.0 \mathrm{ka}$ and $5.0 \mathrm{ka}$ BP. During the entire late Holocene after $4.8 \mathrm{ka} \mathrm{BP}$, reconstructed mean $T_{\text {July }}$ remained below modern value. Limnological conditions did not change significantly. The inference of a mid-Holocene climate optimum supports scenarios of Holocene climatic changes in the subpolar part of eastern Siberia and indicates climate teleconnections to the North Atlantic realm.
\end{abstract}

(c) 2012 Elsevier Ltd and INQUA. All rights reserved.

\section{Introduction}

The reconstruction of past Holocene environments is important for understanding of the background of natural climate variability underlying anthropogenic influences on climate change. Though the timing of Holocene climate change is well established for wide parts of the Northern Hemisphere (Mayewski et al., 2004), suitable palaeoenvironmental records are still scarce in the Russian Siberian Arctic and sub-Arctic, due to such factors as complex periglacial landscape history, low sedimentation rates in sedimentary archives, and logistical challenges for field work in the remote and extreme periglacial environment (Hubberten et al., 2004; Schirrmeister et al., 2011).

\footnotetext{
* Corresponding author. Alfred Wegener Institute for Polar and Marine Research, Periglacial Research, Telegrafenberg A43, 14473 Potsdam, Germany.

E-mail address: larisa.nazarova@awi.de (L. Nazarova).
}

At the present state of knowledge, biological indicators from aquatic (chironomids, diatoms, ostracods, cladocera) and terrestrial environments (pollen, plant macrofossils) are the most reliable proxies, because they react sensitively to climate change and define different aspects of environments, which should be assessed together for reliable reconstructions (Smol et al., 2005; Solovieva et al., 2005, 2008; Kienast et al., 2011; Self et al., 2011; Palagushkina et al., 2012; Pestryakova et al., 2012). The basis, however, of all quantitative reconstruction approaches are regional calibration datasets from which the empirical reconstruction models (i.e. the transfer functions) are established. There are few examples of quantitative palaeoclimate reconstructions in Siberia, and those are mainly from pollen studies (Andreev and Klimanov, 2005; Müller et al., 2009; Andreev et al., 2011; Tarasov et al., 1999, 2009). To date, there is only one quantitative temperature reconstruction inferred from aquatic diatoms in central Siberia (Kumke et al., 2004). Quantitative reconstruction of $T_{\text {July }}$ inferred 
from diatom assemblages of the Lake Lama (central Siberia) had been performed using a calibration data set from north-western Finnish Lapland (Kumke et al., 2004). The temperature variations for Younger Dryas and Holocene reconstructed from pollen by Andreev et al. (2004a) from the same lake sediments are up to $6^{\circ} \mathrm{C}$, whereas the diatom-based temperatures are $1.6{ }^{\circ} \mathrm{C}$, which means $4.4 \mathrm{C}^{\circ}$ difference in the reconstructed temperature range. Pollen reconstructions for Nikolay Lake, Northern Yakutia (Andreev et al., 2004b) were made using temperature model based on an extensive database from the former USSR. The model is rather statistically robust (e.g. mean prediction error for $T_{\text {July }} \pm 1{ }^{\circ} \mathrm{C}$ ). However, as underlined in the results of the investigation, statistical errors in the pollen-based climate reconstructions for the Russian Arctic must be larger, due to the fact that the Arctic region is poorly represented in the data set. The main drawback of the quantitative reconstruction approach was the lack of a regional calibration datasets and regional transfer functions.

Recently, lakes of different origin were systematically studied along environmental gradients in eastern Siberia and checked for their inventories of preserved chironomid assemblages in lake sediments. These studies resulted in the development of the modern chironomid-based temperature and water depth calibration data sets (training sets) for Yakutia, NE Siberia (Nazarova et al., 2011). These data sets and derived quantitative transfer functions have provided a new tool for qualitative assessment of the past environment in northeastern Siberia.

This paper presents the findings from a study of a $380 \mathrm{~cm}-\mathrm{long}$ Holocene sediment core, recovered from Lake Temje (central
Yakutia). The specific aim is to provide reconstructions of mean July air temperature ( $T_{\text {July }}$ ) and water depth (WD) during the last 10,000 years, using the newly developed chironomid-inferred mean July temperature and water depth model published by Nazarova et al. (2011). In addition, the depositional boundary conditions of the lake development are revealed by sedimentological data. The resulting reconstructions of the lake history and ecology are discussed in context of other palaeoecological records and reconstructions of regional climate changes.

\section{Regional setting}

Lake Temje is located in central Yakutia, about $13 \mathrm{~km}$ east of Yakutsk (Fig. 1). Central Yakutia represents one of Earth's most extreme semi-arid continental settings with pronounced seasonal climatic gradients and deep permafrost. According to Gavrilova (1973), the observed long-term climate in the region is characterized by minimum air temperatures of $-63^{\circ} \mathrm{C}$ in January, maximum air temperatures of $38^{\circ} \mathrm{C}$ in July. Modern mean July air temperatures in central Yakutia are between 16.6 and $17.5^{\circ} \mathrm{C}$. Annual precipitation is around $200 \mathrm{~mm}$. The annual evaporation is approximately $350 \mathrm{~mm}-400 \mathrm{~mm}$. Thus, there is a moisture deficit of $150-200 \mathrm{~mm} /$ a. The summer period is short, lasting from the middle of June to the beginning of August. The study region is located within the boreal coniferous forest zone. The vegetation is dominated by taiga, such as larch (e.g., Larix dahurica), pine (e.g., Pinus sylvestris) and birch trees (e.g., Betula pendula) (Kumke et al., 2007).

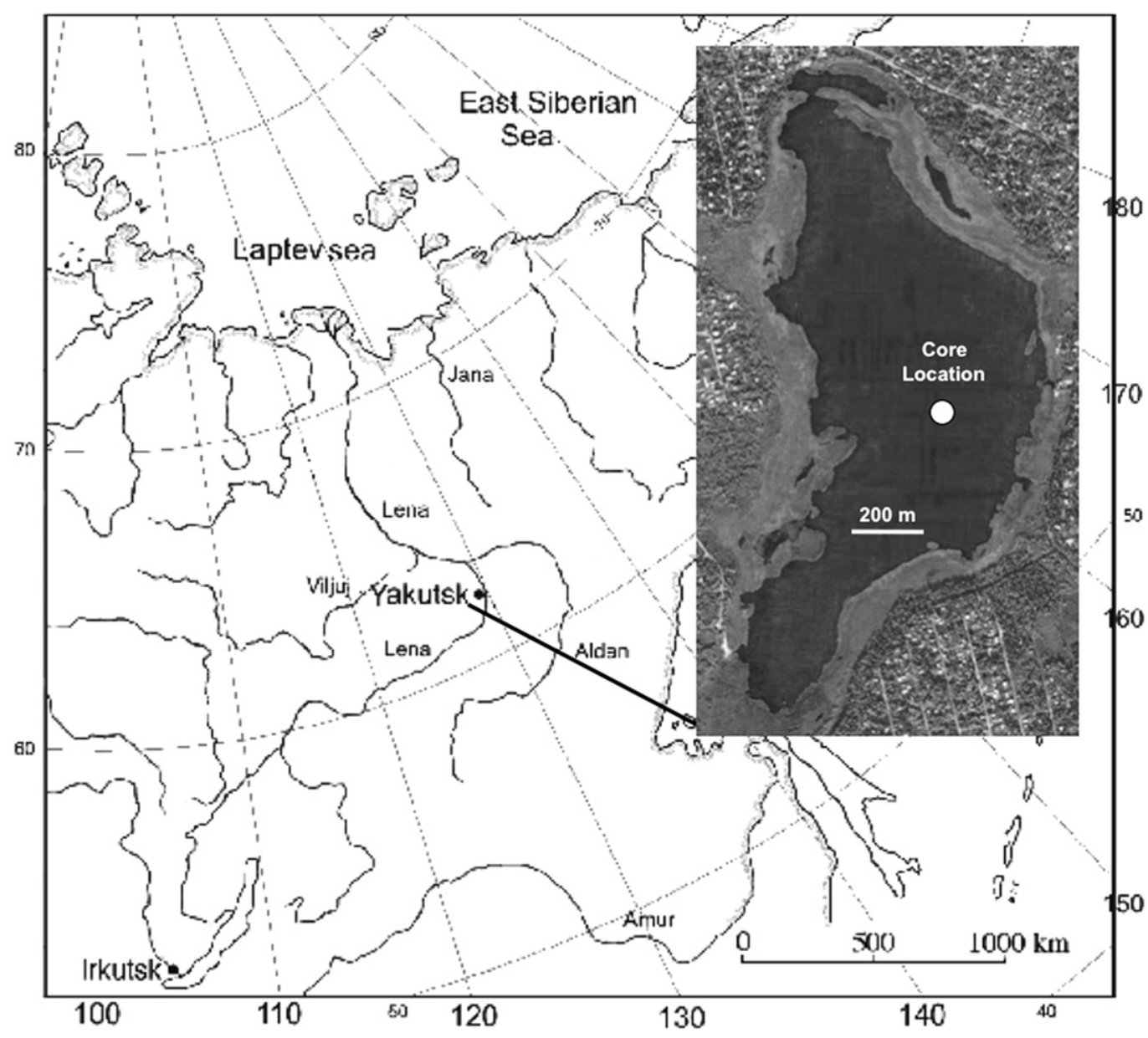

Fig. 1. Location of Lake Temje in central Yakutia. 
The study site, Lake Temje $\left(62^{\circ} 03^{\prime} \mathrm{N}, 129^{\circ} 29^{\prime} \mathrm{E}\right)$ (Fig. 1) is a thermokarst lake located $13 \mathrm{~km}$ east of Yakutsk on the Magane Terrace, west of the Lena River at ca. $208 \mathrm{~m}$ a.s.l. Modern $T_{\text {July }}$ for the vicinity of lake Temje is $17{ }^{\circ} \mathrm{C}$ (New et al., 2002). The lake basin is underlain by sands and sandstones of Jurassic age. The lake is shallow, with a maximum depth of $75 \mathrm{~cm}$. The surface area is $0.32 \mathrm{~km}^{2}$. The lake has no permanent inflows and outflows.

\section{Material and methods}

\subsection{Field work}

The lake sediments were recovered as part of a joint RussianGerman expedition to Yakutia in July 2004. Sampling was performed from two connected rubber boats in the central part of Lake Temje at $70 \mathrm{~cm}$ water depth with a rod-operated half-tube corer (Russian peat corer: $5 \mathrm{~cm}$ in diameter, $100 \mathrm{~cm}$ long sampler). Overlapping core sections yielded a 380 -cm-long sediment-core sequence. The core sections were described and sampled at $5-\mathrm{cm}$ intervals in the field. According to the applied age model (Section 3.3), this spacing yielded a temporal resolution between 60 and 300 years, with the best resolution for the mid-Holocene part. The taken samples were transported to the Alfred Wegener Institute for Polar and Marine Research (AWI) in Potsdam, Germany, and stored at $4{ }^{\circ} \mathrm{C}$. In the AWI laboratory, the samples were divided into subsamples for further micropalaeontological and sedimentological studies.

\subsection{Sediment analysis}

One set of subsamples were weighted in wet condition, freezedried, and weighed again to estimate the water contents. Weight concentrations in total organic carbon (TOC), total carbon (TC), and total nitrogen (TN) contents have been estimated chromatographically on milled samples, using a Vario ${ }^{\mathrm{TM}}$ CNS Elementanalyser. The data were used to calculate the TOC/TN ratio, using a factor of 1.167 to obtain the atomic ratio (Fig. 2). Calcium carbonate weight concentrations were calculated from the inorganic carbon contents, the difference between TC and TOC, multiplied by a factor of 8.33 to include the stoichiometric contributions from calcium and oxygen. Inorganic carbon concentrations were below the limit of detection in the middle and upper parts of the sediment core. Therefore, Xray diffraction analysis (XRD) was conducted to check both the presence of carbonate and the mineralogical composition of carbonate, which solely consists of calcite (XRD peak at $3.027 \AA$ ). The XRD data were also used to check the relative amount of quartz (XRD peak at $3.34 \AA$ ). XRD measurements were undertaken on random powder mounts, using a Philips PW1820 goniometer at AWI Bremerhaven ( $40 \mathrm{kV}, 40 \mathrm{~mA}$, from 3 to 100 , step-rate 0.05 , Co $\mathrm{k} \alpha$ radiation). More details concerning the applied methods can be found in previous publications (Lüpfert, 2006; Biskaborn et al., 2012).

\subsection{Radiocarbon dating}

Five AMS radiocarbon dates were obtained from macroscopic plant remains collected from the lake sediments (Table 1 ). The AMS radiocarbon dating was performed in Leibniz-Laboratory for Radiometric Dating and Stable Isotope Research, Kiel University, using the radiocarbon Accelerator Mass Spectrometry (AMS) ${ }^{14} \mathrm{C}$ method. The radiocarbon dates were calibrated and converted into calendar ages, using the CalPal Online program (Danzeglocke et al., 2010). The applied age model was obtained by assuming linear sedimentation rates between the calibrated dates and a recent age of the surface sediments. Also presented (Fig. 2) are extrapolated ages between the two uppermost dates to the sediments. In this case, the sediments of the last 2800 years are absent. Nonetheless, there is no lithological evidence for an assumption that erosional processes and removal of sediments during the late Holocene in the almost closed lake basin took place. However, if such processes played a role in the past, they potentially could lead to a systematic dating error. Another source of errors might be related to the presence of hard-water conditions in the early Holocene, when the lake deposits were enriched in carbonate precipitates. It is difficult

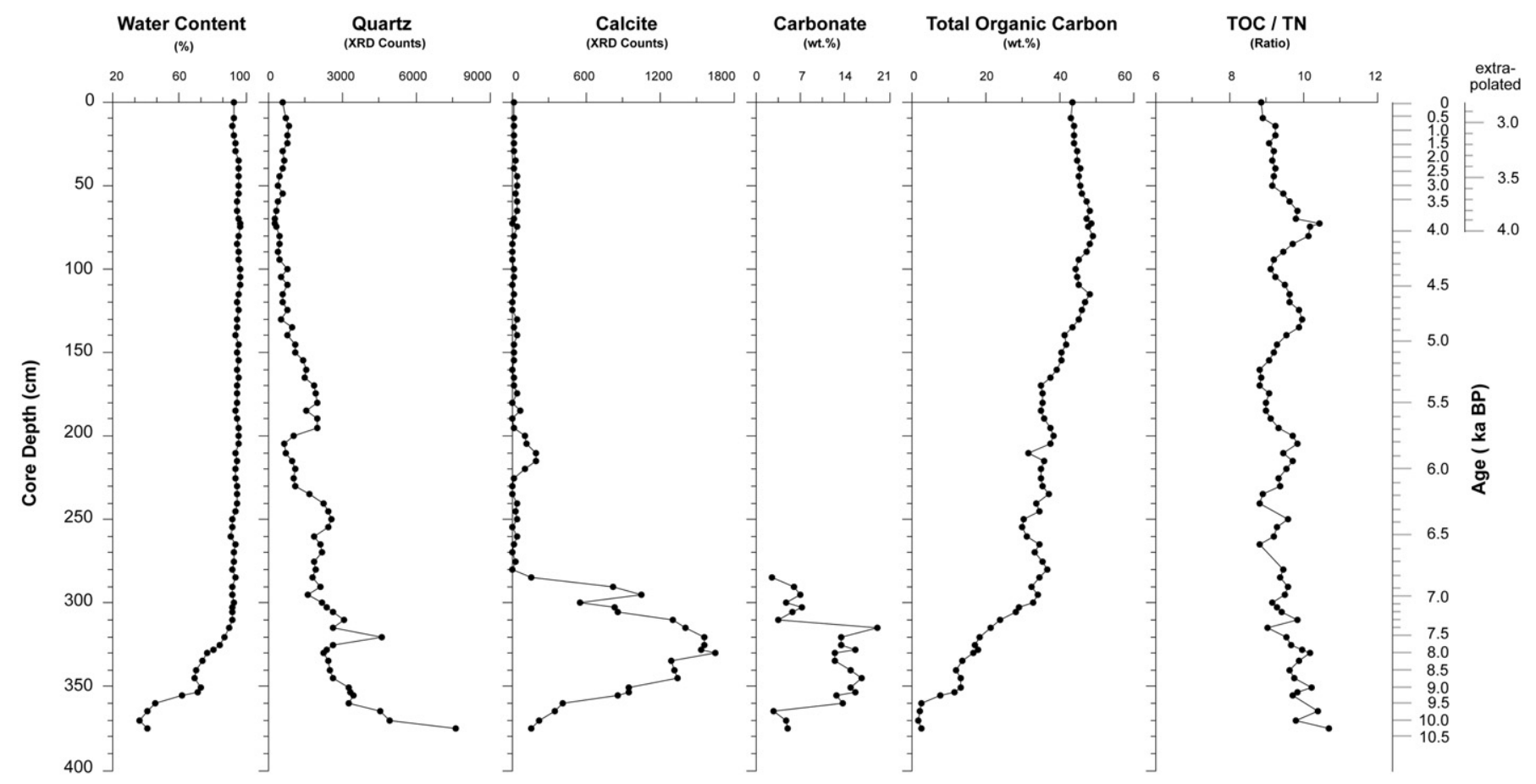

Fig. 2. Variations of compositional parameters in the Lake Temje sediment core (abbreviations: XRD =X-ray diffraction, wt.\% $=$ weight percentage). 
to ascertain this influence without any independent dating. Therefore, the conservative approach was followed, with linear interpolation of given calibrated ages. The final age model was obtained by assuming linear sedimentation rates between the ${ }^{14} \mathrm{C}$ calibrated dates (Fig. 3).

Table 1

Radiocarbon dates from the Lake Temje sediment core. The radiocarbon dates were calibrated and converted into calendar ages, using the CalPal Online program (Danzeglocke et al., 2010).

\begin{tabular}{llllc}
\hline $\begin{array}{l}\text { Sediment } \\
\text { depth }(\mathrm{cm})\end{array}$ & $\begin{array}{l}\text { Material } \\
\text { dated }\end{array}$ & $\begin{array}{l}\text { Laboratory } \\
\text { code \# }\end{array}$ & $\begin{array}{l}\text { Conventional } \\
{ }^{14} \text { C age }(\mathrm{BP})\end{array}$ & $\begin{array}{l}\text { Calibrated } \\
\text { age (BP) }\end{array}$ \\
\hline 62 & Plant remains & KIA26376 & $3487 \pm 28$ & $3771 \pm 46$ \\
155 & Plant remains & KIA26377 & $4350 \pm 25$ & $5190 \pm 96$ \\
290 & Plant remains & KIA26378 & $6040 \pm 60$ & $6895 \pm 81$ \\
320 & Plant remains & KIA29871 & $6645 \pm 40$ & $7531 \pm 34$ \\
370 & Plant remains & KIA26560 & $8895 \pm 50$ & $10,038 \pm 101$ \\
\hline
\end{tabular}

\subsection{Chironomid analysis}

Treatment of sediment samples for chironomid analysis followed standard techniques described in Brooks and Birks (2000). Subsamples of wet sediments were deflocculated in $10 \% \mathrm{KOH}$, heated to $70^{\circ} \mathrm{C}$ for up to $10 \mathrm{~min}$, to which boiling water was added, and left to stand for another $20 \mathrm{~min}$. Subsequently, the sediment was passed through stacked 125 and $90 \mu \mathrm{m}$ sieves. Chironomid larval head capsules were picked out of a grooved Bogorov sorting tray using fine forceps under a stereomicroscope at 25-40 magnifications. To capture the maximum diversity of the chironomid population, 50-147 chironomid larval head capsules were extracted from each sample. Several studies have demonstrated that this sample size is adequate for a reliable estimate of inferred temperature (Heiri and Lotter, 2001; Larocque, 2001; Quinlan and Smol, 2001). Larval head capsules were mounted two at a time in Euparal or Hydromatrix, ventral side up, under a $6 \mathrm{~mm}$ diameter cover slip, with ten cover slips per microscope slide. In total, 4921 chironomid head capsules were slide-mounted and identified to the highest taxonomic resolution possible, with reference to Wiederholm (1983) and Brooks et al. (2007).

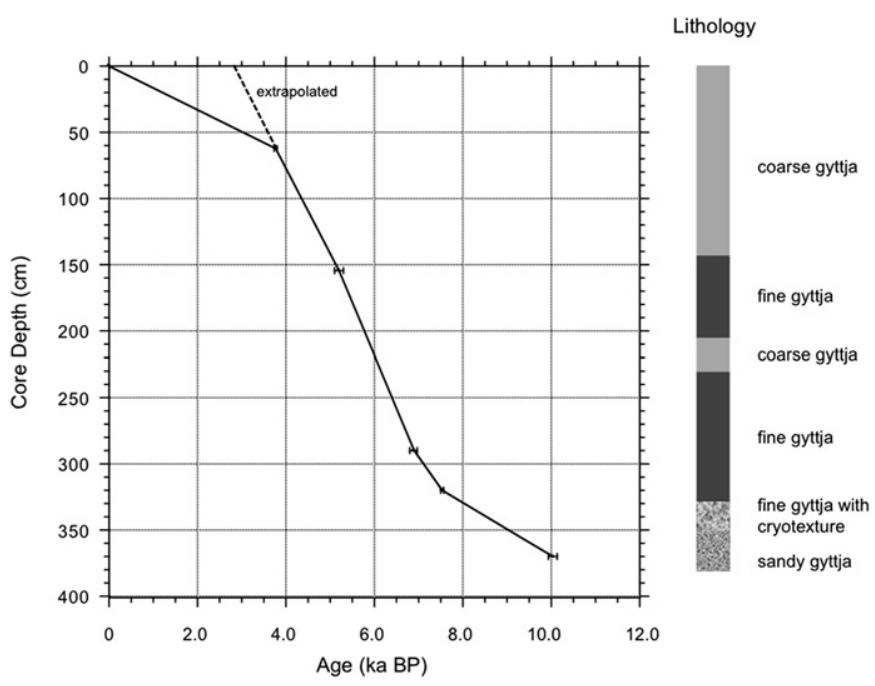

Fig. 3. Age-depth model and lithology of the Lake Temje sediment core. Calibrated age dates with 2 -sigma error range (see Table 1) are plotted against downcore depth. The age model is designed under the assumption of the presence of recent surface sediment. The dotted line indicates extrapolated ages from the older datum points.
A chironomid-percentage stratigraphic diagram was made in $\mathrm{C} 2$ version 1.5 (Juggins, 2007) (Fig. 4). Zonation of the chironomid stratigraphy was made, using the optimal sum-of-squares partitioning method (Birks and Gordon, 1985) using the program ZONE (Lotter and Juggins, 1991), where the number of significant zones was assessed by a broken stick model (Bennett, 1996) using BSTICK (Birks and Line unpublished). The diversity and evenness of the chironomid assemblages were estimated using the ShannonWiener Index (H) and Pielou Evenness Index (I) (Pielou, 1966). Effective numbers of occurrences of chironomid taxa were estimated by Hill's N2 index (Hill, 1973).

\subsection{Statistical treatment of chironomid data}

Detrended Correspondence Analysis (DCA) was performed to examine trends within the chironomid data and to determine whether linear or unimodal based numerical techniques should be used (Birks, 1995). Mean July air temperatures ( $\left.T_{\text {July }}\right)$ and water depths (WD) were reconstructed, using a modern chironomidbased temperature and water depth calibration data sets (training sets) from Yakutia (Nazarova et al., 2011). $T_{\text {July }}$ training set contains 143 lakes spanning the temperature gradient from 3.4 to $18.8^{\circ} \mathrm{C}$. Two-component $T_{\text {July }}$ Weighted-averaging partial least squares (WA-PLS) model had the best performance: coefficient of determination $r^{2}$ boot $=0.87$, root mean square error of prediction $($ RMSEP $)=1.93$. WD training set includes 147 lakes that are $0.1-$ $17.1 \mathrm{~m}$ deep. For WD, the one-component WA-PLS model had the best performance: $r^{2}$ boot $=0.62$, RMSEP $=0.35$.

In order to evaluate the reconstructed palaeotemperatures, a principal components analysis (PCA) was performed with the fossil species from each sample of the sediment core. The PCA is an eigenanalysis from which eigenvalues $\lambda_{k}$ (where $k$ is a principal axis) and eigenvectors $u_{k}$ are derived. The eigenvectors corresponding to the largest $k$ represent most of the variance in the species data. The position of the objects $\mathbf{f}_{k}$ (i.e., the sample scores) at each principal axis $k$ is a linear combination of the centered values for each species and $\mathrm{u}_{k}$. The values of $\mathbf{f}_{k}$ were scaled to the square root of $(n-1) \lambda_{k}$. The sample scores of the first few PC axes were compared to the reconstructed temperatures and water depths, because the variability of $\mathbf{f}_{k}$ is, at least theoretically, determined by the first few ecological gradients of the species. Ideally, $\mathbf{f}_{k}$ should be dominated mainly by the variable being reconstructed (Kumke et al., 2004).

Percentage abundances of the fossil chironomids that are absent or rare in the modern Yakutian calibration data set (Engels et al., 2010) were calculated. A taxon is considered to be rare in the modern data when it has a Hill's N2 (Hill, 1973) below 5. Optima of taxa which are rare in the modern data are likely to be poorly estimated (Brooks and Birks, 2001).

In addition, an analysis of analogues between the samples of the calibration dataset and the chironomids from the core samples was carried out. The analogue analysis involves the computation of dissimilarities between the assemblages of the calibration data and the core data, using the $\chi^{2}$-square distance as the dissimilarity coefficients. Following the modern analogue technique described in Birks et al. (1990), the cut-off levels of the 2nd and 5th percentiles of all squared $\chi^{2}$-distances in the modern calibration data were determined and used to define 'no close' and 'no good' analogues when comparing the distance between an individual fossil assemblage and the most similar assemblage in the modern data set.

DCA and PCA were performed using CANOCO 4.5 (ter Braak and Šmilauer, 2002). Chironomid abundance data were square-roottransformed. 


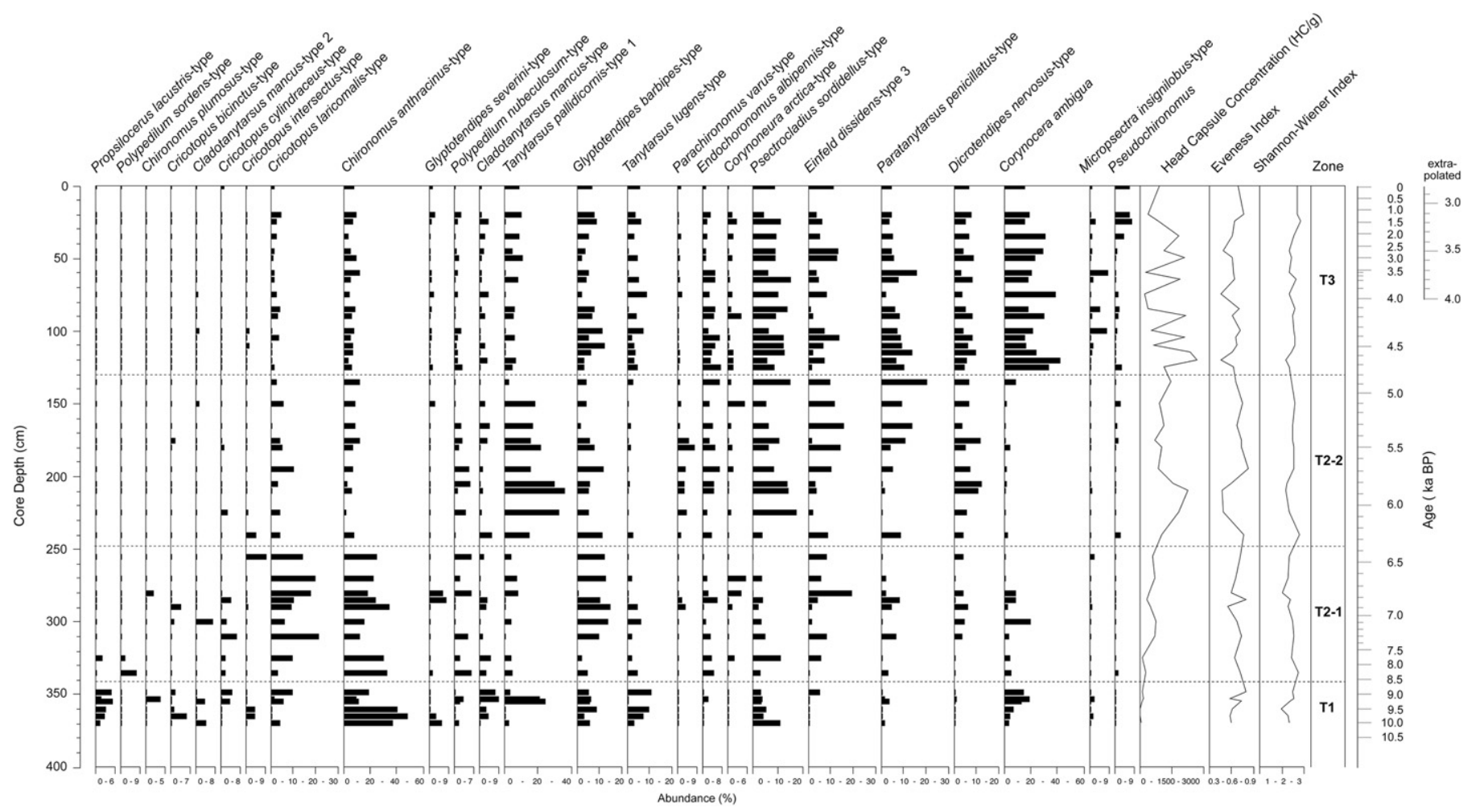

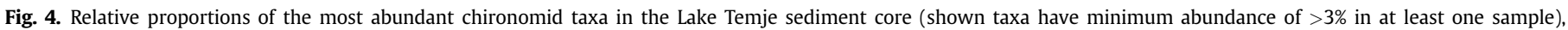

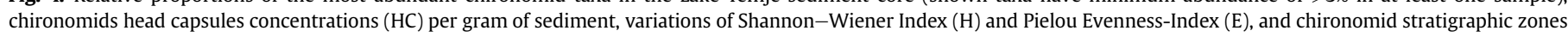
(T1-T3).

\section{Results}

\subsection{Sediment composition and depositional environment}

The $380 \mathrm{~cm}$ long sediment core revealed a sequence of strongly water-saturated gyttja, admixed with sand in the lower $30 \mathrm{~cm}$ (Fig. 3). In the lower part, water concentrations steadily drop from about $90 \%$ to about $40 \%$ due to compaction and lithological change (Fig. 2). Apart from the basal sand layer, high concentrations of total organic carbon (TOC) that range between 20 and more than $40 \mathrm{wt} . \%$ reflect the high amount of organic matter in the gyttja. The lowermost gyttjas $(330-360 \mathrm{~cm})$ reveal a crumbly and friable texture, similar to freeze-dried instant coffee. Such textures have rarely been described in the literature, but seem to be related to permafrost. Teller and Last (1982) report similar features in postglacial lake sediments of Canada, that possibly resulted from the freezing of lake water down to the lake bottom with the effect of moisture migration out of the lake sediment into the lake ice. Repeated loss and gain of pore-water through the seasons then leads to shrinkage of the lake sediments, documented in the crumbly structure of the sediment. Alternatively, the formation of small ice crystals in the sediments may cause the friable character. Similar cryotextures were also described by Wetterich et al. (2008) for fossil lake sediments in the Kolyma region of northeastern Siberia. For the Lake Temje record, the cryotextures are interpreted to document the invasion of the seasonal freezing zone into the lake sediments and that this process may have occurred frequently prior to $8.0 \mathrm{ka} \mathrm{BP}$. As the overlying younger sediments do not show signs of cryotextures, the freeze-drying effect did not occur during the remaining part of the Holocene.

The atomic TOC/TN ratios in the gyttjas of Lake Temje show low variability in the range between 9 and 11 and are interpreted to reflect the sources of organic matter. Such low values usually point to a high abundance of organic remains from planktonic algae with only small contributions from higher land plants and/or macrophytes from near-shore areas (Meyers and Teranes, 2001). The low variability of TOC/TN ratios points to a persistent pelagic depositional environment through the investigated time interval, though at shallow water conditions (as shown by the fossil chironomids, presented in the following Section 4.2). Variations in TOC concentrations result from relative dilution effects by other sediment components. Thus the continuous upcore increase in TOC between 10.0 and $4.0 \mathrm{ka} \mathrm{BP}$ is mirrored by decreasing quartz concentrations (Fig. 2). This trend documents a systematic decline in detrital sediment supply.

The lacustrine sediments of the time interval between 10.0 and $7.0 \mathrm{ka}$ BP include relatively high amounts of carbonate (around 15\%) composed of calcite (Fig. 3). The carbonate fraction has not been studied in detail. Nonetheless, visual inspection of the gyttja exhibited ostracod remains and micritic carbonate as main carbonate constituents. Thus the carbonate is of both endogenic (precipitates) and biogenic origin. Such lacustrine carbonates are mostly related to hard-water lakes with elevated $\mathrm{pH}$ values (Dean, 1999). In summer 2004, when the lake was cored, $\mathrm{pH}$ of the surface layer of lake water was 8 (slightly alkaline). In the modern and young sediments, calcite is only present in trace amounts (Fig. 2). The carbonate-rich section in the older part of the record thus gives evidence of higher $\mathrm{pH}$ values during the early lake development.

In summary, the depositional environment was dominated by organic sedimentation. According to the applied age model (Fig. 2), maxima in sediment accumulation rates appeared between roughly 7.5 and $5.2 \mathrm{ka} \mathrm{BP}$ at $0.7-0.8 \mathrm{~mm} / \mathrm{a}$, documenting enhanced biological productivity and sediment preservation during that time, while the older sediments $(0.25 \mathrm{~mm} / \mathrm{a})$ and younger sediments $(0.16 \mathrm{~mm} / \mathrm{a})$ are condensed. 


\subsection{Chironomid stratigraphy}

In total 4921 chironomid head capsules (HC) were recovered and slide-mounted from the 42 samples of the investigated sediment core. The average count was $118 \pm 65 \mathrm{HC}$ per sample with a minimal count of $50 \mathrm{HC}$ and a maximal count of $335 \mathrm{HC}$ per sample. Chironomid concentrations varied between 35 and 2710 $\mathrm{HC} / \mathrm{g}$ of dry sediment, with a mean value of $950 \mathrm{HC} / \mathrm{g}$. The lowest concentration of $\mathrm{HC}$ was at the base of the sediment core and the highest $\mathrm{HC}$ concentration in the upper part of the core (Fig. 4). In total, 52 chironomid taxa were identified. Due to a lack of taxonomically important features, $246 \mathrm{HC}$ could not be identified to species group. Among them, $242 \mathrm{HC}$ belonged to the tribe Tanytarsini and four HC belonged to the subfamily Orthocladiinae. The most abundant taxa were Corynocera ambigua (799 HC in total, $16.2 \%$ of the total number of the HC), Chironomus anthracinus-type (487 HC, 9.9\%), Psectrocladius sordidellus-type (433 HC, 8.8\%), and Paratanytarsus penicillatus-type ( $403 \mathrm{HC}, 8.2 \%$ ). The number of taxa per sample varied throughout the core from 12 to 27 with a mean of 19 taxa. Taxonomic richness was slightly lower at the bottom of the core and increased towards the sediment surface. ShannonWiener Index, a measure of biodiversity and the trophic state of the ecosystem, varied very little throughout the core with minimal values of 1.99 at the base of the core and maximal values of 2.82 in the middle part of the core, averaging 2.5, characteristic for $\beta$ mesotrophic to oligotrophic conditions (Sladecek, 1973). Pielou Evenness Index, a measure of ecosystem stability remained relative high (mean 0.65) throughout the majority of the core but declined slightly in the upper part of the core, indicating some changes in the ecological conditions (Smirnov, 1993). The down-core changes in the chironomid assemblages led to the identification of three statistically significant zones ( T 1 - T 3). Zone 2 was subdivided into two subzones T 2-1 and T 2-2 (Fig. 4) based on a strong shift in dominant taxa from $C$. anthracinus-type to Tanytarsus pallidicornistype 1 .

\subsubsection{Zone T $1(370-349 \mathrm{~cm}, 10-8.2 \mathrm{ka} \mathrm{BP})$}

At the bottom of this zone, the chironomid assemblage is dominated by $C$. anthracinus-type reaching a maximum of $46 \%$ at $365 \mathrm{~cm}$ depth ( $9.5 \mathrm{ka}$ BP) and Tanytarsus lugens-type. These are both cold stenothermic taxa which usually occur in cold subalpine or subarctic lakes (Brundin, 1956; Brodin, 1986). At $355 \mathrm{~cm}$ depth (9.5 ka BP), C. anthracinus-type declines to $15 \%$ abundance and T. lugens-type disappears. These taxa are replaced by T. pallidicornistype, a taxon that prefers warmer conditions (Nazarova et al., 2008, 2011). C. ambigua gradually increases in abundance throughout this zone from 2 to $18 \%$ and Propsilocerus lacustris-type, although not very abundant, is only present in this zone. These three taxa are characteristic of meso- to eutrophic conditions (Brooks et al., 2007). $P$. lacustris is reported to be indicative of hypertrophic lakes (Kornijów and Halkiewicz, 2007). The chironomid abundances in the zone, with a mean of $104.3 \mathrm{HC} / \mathrm{g}$, are the lowest values for the core. The average reconstructed $T_{\text {July }}$ for this zone is up to $2{ }^{\circ} \mathrm{Cl}$ lower than the present day $T_{\text {July }}$ value (reconstructed $T_{\text {July }}$ mean is $15.6 \pm 0.7^{\circ} \mathrm{C}$; Fig. 5).

Reconstructed WDs show minor changes throughout the core and range between 80 and $120 \mathrm{~cm}$. All the fluctuations in reconstructed water depth lie within the mean error of prediction of the inference model (RMSEP $=0.35$ ) so it is not possible to draw conclusions from the reconstructions.

\subsubsection{Zone T 2-1 (349-240 cm, 8.2-6.3 ka BP)}

This zone is dominated by C. anthracinus-type (22.6\% in average) and Cricotopus laricomalis-type (11.3\%). Abundances of

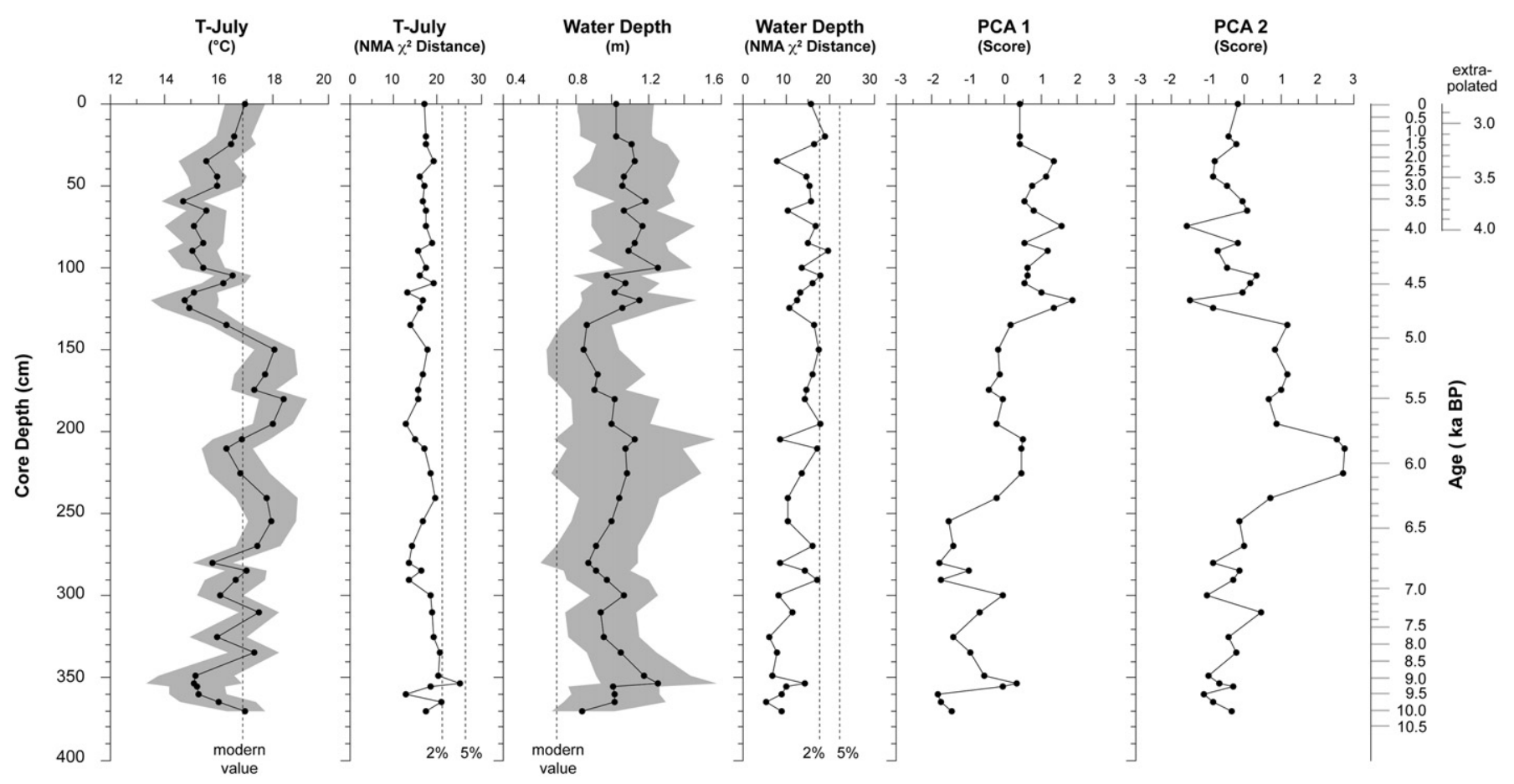

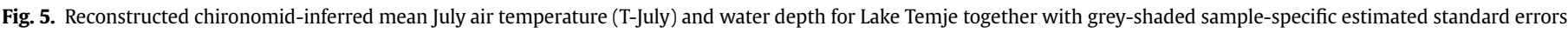

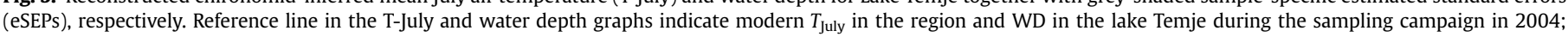

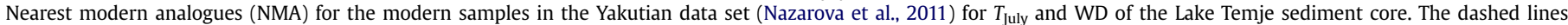

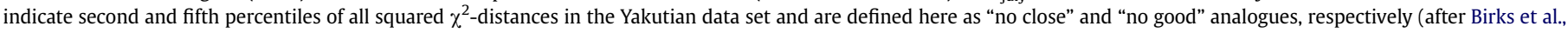
1990). 
other Cricotopus taxa are also highest in this and the previous zone. Increases in the abundance of Cricotopus taxa can be indicative of the expansion of submerged vegetation (Cranston et al., 1983). T. pallidicornis-type declines and, although present, is not found in all samples and is at low abundances when it does occur. C. ambigua also gradually declines, and is present at high abundance only at $300 \mathrm{~cm}$ depth $(\sim 7.0 \mathrm{ka}$ BP). In this zone, Dicrotendipes nervosus-type, a thermophilic taxon that is also often associated with macrophytes (Moller Pillot and Buskens, 1990), appears for the first time and remains present till the end of the core. The concentration of chironomid HC increases throughout the zone to a mean of $557.5 \mathrm{HC} / \mathrm{g}$.

The reconstructed $T_{\text {July }}$ fluctuates between 16.0 and $18.0{ }^{\circ} \mathrm{C}$ with the highest values reconstructed for the upper part of the subzone. The average $T_{\text {July }}$ for this subzone is $16.9 \pm 0.9{ }^{\circ} \mathrm{C}$.

\subsubsection{Zone $T 2-2(240-135 \mathrm{~cm}, 6.3-4.8 \mathrm{ka} \mathrm{BP})$}

C. anthracinus-type declines noticeably in this subzone, to approximately $6.8 \%$, whilst $T$. pallidicornis-type becomes the most abundant taxon doubling the abundances seen throughout the other three zones and reaching a maximum of $31 \%$. C. ambigua nearly disappears from the chironomid assemblage. The acidophilic $P$. sordidellus-type is more abundant than previously, reaching a peak of $17 \%$. P. penicillatus-type, Einfeldia dissidens-type, D. nervosus-type and Parachironomus varus-type are not abundant in the core as a whole, but reach their maximum abundances in this zone. All these taxa are indicative of warmer conditions and are associated with macrophytes (Brooks et al., 2007). P. penicillatus-type reaches its maximal abundance of $20 \%$ at the end of the subzone. The concentration of chironomids $\mathrm{HC}$ reaches its maximal value (mean $1318.1 \mathrm{HC} / \mathrm{g}$ ). At the lower part of this subzone $(210 \mathrm{~cm}$, $\sim 5.8$ ka BP) very high HC concentrations are observed coincidence with a pronounced decline in $\mathrm{H}$ und I indices.

The reconstructed $T_{\text {July }}$ is the highest for the entire core, $T_{\text {July }}$ varies from 16.3 to $18.4{ }^{\circ} \mathrm{C}$ with a mean of $17.3 \pm 0.8{ }^{\circ} \mathrm{C}$. Temperature remains above the present-day value with some decline in the middle of this subzone around $5.8 \mathrm{ka}$ BP. Reconstructed WDs are the lowest for the whole core with the slight increase towards the end of the zone.

\subsubsection{Zone T 3 (135-0 cm, $4.8 \mathrm{ka} \mathrm{BP}$ - younger than $4.8 \mathrm{ka} \mathrm{BP})$}

C. anthracinus-type and $C$. laricomalis-type remain at low abundances, similar to those in the subzone $\mathrm{T} 2-2$ whilst T. pallidicornis-type declines strongly and appears only sporadically in abundances of less than 10\%. C. ambigua dominates throughout the zone, reaching abundances of more than $40 \%$. The abundances of $D$. nervosus-type, $P$. sordidellus-type and $E$. dissidens-type remain similar to those in zone T 2-2. Other taxa indicative for macrophytes, such as Endochironomus albipennis-type and P. penicillatustype, decline towards the top of the sediment core. Micropsectra insignilobus-type and Pseudochironomus appear for the first time, with abundances above $5 \%$, in this zone only. The cold stenotherm $M$. insignilobus-type appears in the middle of the zone, and Pseudochironomus, an indicator of relatively warm conditions, low total phosphorus and high Secchi depth (Brooks et al., 2007; Nazarova et al., 2011) is recorded in the top four analysed horizons of the zone. The concentration of chironomids HC varies widely throughout this zone.

The reconstructed $T_{\text {July }}$ decreases sharply from subzone T 2-2 and zone $\mathrm{T} 3$. It remains below the present-day value throughout the entire zone T3 but after $3.8 \mathrm{ka}$ BP shows a gradual increase towards the top of the core and reaches modern values. The reconstructed $T_{\text {July }}$ fluctuates between 14.7 at the lower part of this zone and $16.9{ }^{\circ} \mathrm{C}$ at the upper part of the zone. The average $T_{\text {July }}$ for this subzone is $15.6 \pm 0.7^{\circ} \mathrm{C}$, which is below modern $T_{\text {July }}$ values.

\subsubsection{Quality of the chironomid-based $T_{\text {July }}$ and $W D$ reconstructions}

The numerical evaluation is an important consideration when applying quantitative chironomid-based reconstruction methods to palaeoecological data (Birks, 1998). This is especially important in the regions, where no quantitative reconstructions have been done before. As inference models produce numbers, even if the calibration data set does not contain the necessary ecological information to reliably reconstruct past environments from the fossil samples, several statistical techniques were used to test the reliability of the reconstructed $T_{\text {July }}$ and WD (Birks et al., 1990; Birks, 1995, 1998): correlation of the first PC axes to the reconstructed temperatures and water depths; taxonomic fit of the fossil data set with the modern data set; and modern analogue statistics (Fig. 5). The gradient lengths of species scores were relatively short. DCA axes 1 and 2 were 1.71 and 1.41 standard deviation units respectively, indicating that numerical methods based on a linear response model were the most appropriate to assess the variation structure of the chironomid assemblages (ter Braak, 1995). PCA axes 1 and 2 together explain $60.2 \%$ of distribution of the chironomid data, with axis 1 explaining $36.4 \%$ and axis 2 explaining $23.8 \%$ of the variance. The first two PCA axes, which are the major hypothetical gradients in PCA, are significantly correlated with the inferred air temperatures and water depths. WD significantly correlates with PCA axis $1\left(r_{1}=0.56\right.$, and $\left.r_{2}=0.23, p \leq 0.05\right)$ and inferred $T_{\text {July }}$ significantly correlates with the PCA axis $2\left(r_{1}=0.43\right.$, and $\left.r_{2}=0.53, p \leq 0.05\right)$. The indirect gradient analysis of the fossil assemblages (i.e. the PCA) therefore has shown that the major part of the variability in the chironomid assemblages is driven mainly by temperatureindicative and water depth-indicative taxa. This is supported by the significant correlation of the principal components of the first major axes with the reconstructed temperatures and water depths.

All subfossil taxa present in the chironomid record from Lake Temje are well represented in the Yakutian training set (Nazarova et al., 2011). Only two taxa found in Lake Temje have values for Hill's N2 diversity index below 5 in the modern data set: Cladotanytarsus mancus-type (3.45) and Cricotopus bicinctus (4.60). Hill's N2 values of all other taxa found in the core range between 5.13 and 88.60 providing further support that the quantitative chironomid-based $T_{\text {July }}$ and WD reconstructions are reliable (Brooks and Birks, 2001). Nearly all samples have "close analogue" in the modern calibration data set (Fig. 5). One sample is defined as having "no close" analogues in terms of $T_{\text {July }}$ in the modern Yakutian data set and two sample as having "no close" analogue in terms of WD in the modern Yakutian data set. Therefore the reconstructions are considered as very reliable (Birks, 1998). The reconstructed WDs at the top of the sediment core are slightly deeper than the modern WD of the lake. The difference exceeds the errors of the reconstruction (SEP). WD reconstructions using the chironomid-based WA-PLS inference model (Nazarova et al., 2011) tend to overestimate values at the lower part of the gradient and underestimate values at the deeper part of the gradient. Lake Temje is very shallow, and therefore slight overestimations of the reconstructed WD can be a consequence of the quality of the applied model.

\section{Discussion}

The sediment record of Lake Temje comprises almost the whole Holocene. Three stages in lake development and palaeoecological evolution can be recognized from changes in sediment composition and fossil chironomid assemblages. 


\subsection{Early Holocene (10.0-8.0 ka BP)}

The oldest limnic gyttjas are about $10.0 \mathrm{ka}$ old and are underlain by terrestrial sandy sediments. The formation of the lake basin possibly started sometime between 15.0 and $10.0 \mathrm{ka}$ BP, a time which was characterized by postglacial temperature rise and melting processes in permafrost over eastern Siberia (Baulin and Danilova, 1984; Schirrmeister et al., 2011; Biskaborn et al., 2012). At the same time, steppe vegetation in central Yakutia was gradually declining and being replaced by the spread of larch and birch forests with pine and spruce along river valleys (Andreev et al., 1997; Fradkina et al., 2005; Andreev and Tarasov, 2007; Müller et al., 2009).

During the Early Holocene, the chironomid fauna of the Lake Temje was dominated by cold stenothermic taxa that were gradually replaced by more thermophilic fauna. This period is characterised by high abundances of $C$. ambigua. During the late glacial stage in northern Europe, $C$. ambigua thrived at low temperatures in lakes with silty and low organic sediments, abundant oxygen and probably extensive charophyte beds in carbonate rich waters with high transparency (Brodersen and Lindegaard, 1999). The rapid temperature increase following the Younger Dryas (Coope, 1986), a lowering in water levels (Berglund et al., 1996), extensive erosion, and redeposition of lake sediments (Digerfeldt, 1986) might have caused an increased nutrient availability (Birks, 1980), an outward spread of aquatic macrophytes (Digerfeldt, 1986) and increased organic sedimentation (Birks, 1986). Thus, an overall change in lake type from 'Chara' to 'Potamogeton lakes' (Forsberg, 1965) might have contributed to reduction in C. ambigua populations in northern Europe, just as much as increased temperature. In Lake Temje, increases in the abundance of $C$. ambigua together with the highest reconstructed WD, relatively high carbonate concentrations and an increase in organic matter show that during the Early Holocene the lake was well oxygenated, with high water transparency, and widespread algae beds (most probably Chara algae). Taxonomic composition of chironomid communities and reconstructed $T_{\text {July }}$ indicate colder than presentday climatic conditions. This is also indicated by the presence of cryostructures in the lowermost sediments indicative of permafrost conditions with a totally frozen lake floor, while during the rest of the Holocene no freezing fronts affected the upper lake sediments. Gradual increase in the content of organic carbon from $5 \%$ to $24 \%$ and of nitrogen from $0.3 \%$ to $3.5 \%$ indicate enhanced biological productivity in the lake related to climate amelioration. Chironomid-based reconstructions of increasing air temperature and higher-than-present lake-level points to cool summer conditions that also favoured a change in vegetation in eastern Siberia (Müller et al., 2009).

\subsection{Middle Holocene (8.0-4.8 ka BP)}

Warmer-than-today climatic conditions are inferred for the Middle Holocene in central Yakutia from the Lake Temje chironomid record. An increase in sedimentation rate (Fig. 3) is consistent with high concentrations of organic matter in the lacustrine deposits, giving evidence of strong biological productivity. The lake system changed from a carbonate-rich hard-water lake to a typical Siberian fresh-water lake with dominant gyttja sedimentation and reduced supply of weathering materials from the surrounding catchment. Cold stenothermic taxa were replaced by more thermophilic fauna. Many macrophyte-associated chironomid taxa appeared, indicating the spread of submerged vegetation and algae beds. Reconstructed $T_{\text {July }}$ are up to $1.5 \mathrm{C}^{\circ}$ higher than today. The warmest temperatures fall into the time frame between 6.7 and $5.0 \mathrm{ka}$ BP. Lake level fluctuated slightly with a maximum around $6.0 \mathrm{ka} \mathrm{BP}$, concurrent with a short interval of lower temperatures. Lower lake levels are often associated with higher temperatures, possibly related to stronger evaporation.

\subsection{Late Holocene (4.8 ka BP - present)}

While the lithology of Lake Temje did not change significantly in the late Holocene, chironomid assemblages became dominated by C. ambigua, suggesting a decline in aquatic macrophytes towards the top of the core. The presence of cold stenothermic taxa and reconstructed mean July temperatures indicate climate cooling. The reconstructed $T_{\text {July }}$ remains below the modern value between 4.8 and $3.0 \mathrm{ka} \mathrm{BP}$, then warms to present-day values.

\subsection{Regional comparison}

The inferred stages of Holocene climate and environmental changes in central Yakutia are consistent with findings from other regional palaeoclimate records. The marked palaeoecological change of chironomid habitats observed in Lake Temje between 5.0 and $4.5 \mathrm{ka}$ BP is consistent with climate-related ecological changes in other shallow lakes across central Yakutia, as inferred from fossil diatoms (Pestryakova et al., 2012). The most prominent feature in the record, however, is the presence of an early to mid-Holocene climate optimum. Using a bioclimatic vegetation model, Monserud et al. (1998) reconstructed the peak of postglacial warming in East Siberia for the time interval between 6.0 and $4.6 \mathrm{ka}$ $\mathrm{BP}$, which is in accordance with the reconstruction in the present study. The study of Monserud et al. (1998) has shown that the Siberian winters were $3.7 \mathrm{C}^{\circ}$ warmer than now, and between 63 and $73^{\circ} \mathrm{N}$ the summers were $2-5 \mathrm{C}^{\circ}$ warmer than today. The annual sum of precipitation in Yakutia was more than $200 \mathrm{~mm}$ higher, or approximately double, the present-day values. In three different areas, the northern Ural, the Taimyr Peninsula, and the Lena Delta, temperatures appear relatively high during the early to middle Holocene (Andreev et al., 2003). The investigations of Kremenetski (1996) on Fadeyevsky Island, of Andreev et al. (2001, 2002, 2004a, 2004b) and Anderson et al. (2002) in Northern Siberia, Fradkina et al. (2005) in central Yakutia and Koshkarova and Koshkarov (2004) in northern Central Siberia, and Biskaborn et al. (2012) in the region close to Lena Delta ascertained the climate optimum in comparable periods for several regions from Central to Northern Siberia, although there is also evidence for warmer to warmest periods occurring in the Early Holocene (Pisaric et al., 2001; Andreev et al., 2005). The palynological data from higharctic Holocene sediments of the Kara Sea region (Andreev et al., 1998; Serebryanny et al., 1998) clearly identify the Holocene climatic optimum between 6 and 4 ka (Andreev et al., 1998; Serebryanny et al., 1998). During the Middle Holocene, highlatitudinal air temperatures were significantly higher than now (Frenzel et al., 1992). The deviation from present-day values of annual mean temperature (time interval 6 to 5.5 cal. ka.) is estimated at +3 to $+2 \mathrm{C}^{\circ}$ (Klimanov, 1992) which is $0.5-1.5 \mathrm{C}^{\circ}$ higher than the inferences made from Lake Temje for central Yakutia. In the Verkhoyansk Mountains of northern central Yakutia (Lake Billyakh record), mid-Holocene warming was marked by the establishment of modern-like taiga vegetation and climate warming after 7 ka BP (Müller et al., 2009; Tarasov et al., in this volume). Investigation of stable oxygen and hydrogen isotope ratios of ground-ice wedges in the Verkhoyansk Mountains foreland reflect postglacial climate amelioration at its maximum between $8.5 \mathrm{ka}$ and $4.5 \mathrm{ka}$ BP during the winter season (Popp et al., 2006). The pollen record from Smorodinovoye Lake indicates that midHolocene climatic changes in the upper Indigirka basin resembled 
those in the lake Billyakh area (Anderson et al., 2002). The maximum postglacial warming also occurred after $7 \mathrm{ka} B P$, a few thousand years later than in the northern and northeastern parts of the Arctic region.

Thus, the chironomid-based quantitative reconstruction of the Holocene climate optimum in central Yakutia between 8.0 and 4.8.0 ka BP supports published scenarios. This timing of maximum warming is consistent with postglacial climate development in central and northern Europe (e.g. Davis et al., 2003), suggesting strong climate teleconnections to Europe via the westerly wind system (Müller et al., 2009; Renssen et al., 2009; Biskaborn et al., 2012).

\section{Conclusions}

The palaeolimnological development of Lake Temje through the Holocene is well documented by changes in sediment composition and fossil assemblages of preserved chironomid head capsules. Statistical transfer functions, established from a modern training data set of chironomid remains in modern lake sediments of Yakutia (Nazarova et al., 2011), were applied to the fossil chironomid record for the quantitative reconstruction of the mean July air temperatures and lake water depth during the last $10.0 \mathrm{ka}$. Reconstructed WDs show minor changes throughout the core and range between 80 and $120 \mathrm{~cm}$. This amplitude is close to the statistical error of the reconstruction.

Three stages of climate-related palaeoenvironmental changes, consistent with other regional palaeoclimatic records, could be recognized:

- The early Holocene between 10 and 8 ka BP was characterized by colder-than-today summer conditions with average reconstructed $T_{\text {July }}=15.6 \pm 0.7^{\circ} \mathrm{C}$. A high proportion of endogenic carbonate and detrital sediment components documents water runoff from the catchment, supplying dissolved and solid weathering products. Cryotextures in the lake sediments document full freezing of lake water during winter.

- The chironomid-based quantitative reconstruction of the Holocene climate optimum in central Yakutia between 8.0 and 4.8.0 ka BP supports published scenarios. A general warming trend started around $8.0 \mathrm{ka}$ BP in concert with enhanced biological productivity and fluctuating lake level. Mean $T_{\text {July }}$ up to $1.5 \mathrm{C}^{\circ}$ higher than today are reconstructed between 6.7 and 5.0 ka BP.

- During the late Holocene after $4.8 \mathrm{ka} \mathrm{BP}$, the reconstructed $T_{\text {July }}$ fluctuates between $14.7^{\circ} \mathrm{C}$ at the lower part of this zone and $16.9{ }^{\circ} \mathrm{C}$ at the upper part of the zone. The $T_{\text {July }}$ remains below the modern value between 4.8 and $3.0 \mathrm{ka}$ BP then warm to present-day values.

- The timing of maximum warming is consistent with postglacial climate development in central and northern Europe, suggesting strong climate teleconnections to Europe via the westerly wind system.

\section{Acknowledgements}

We thank all Russian and German colleagues who helped us during the fieldwork in central Yakutia. Many thanks to Dr. A. Andreev for very helpful discussions, to Antje Eulenberg and Ute Bastian (AWI) for the help in laboratory work, to Dr. Evgenia Vinogradova for the help with chironomid slides preparation. Sincere thanks to the reviewers for their valuable comments. This study is part of Russian-German cooperative scientific efforts of the Alfred Wegener Institute for Polar and Marine research.

\section{References}

Anderson, P.M., Lozhkinm, A.V., Brubaker, L.B., 2002. Implications of a 24,000-Yr palynological record for a younger Dryas cooling and for boreal forest development in northeastern Siberia. Quaternary Research 57, 325-333.

Andreev, A.A., Klimanov, V.A., 2005. Late-glacial and Holocene in northeastern Asia. Geological Society of America Bulletin 382, 116-120.

Andreev, A.A., Tarasov, P.E., 2007. Pollen records, Postglacial: northern Asia. In: Elias, S. (Ed.), Encyclopedia of Quaternary Science, vol. 4. Elsevier, Amsterdam, pp. 2721-2729.

Andreev, A., Klimanov, V.A., Sulerzhitsky, L.D., 1997. Younger Dryas pollen records from central and southern Yakutia. Quaternary International 41-42, $111-117$.

Andreev, A.A., Tarasov, P.E., Romanenko, F.A., Sulerzhitskii, L.D., Terekhov, K.I., 1998. Vegetation of the western coast of the Baidaratskaya Bay at the end of the Late Pleistocene. Stratigraphy and Geological Correlation 6, 520-523.

Andreev, A.A., Peteet, D.M., Tarasov, P.E., Filimonova, L., Romanenko, F.A., Sulerzhitsky, L.D., 2001. Late Pleistocene interstadial environment on Fadeyevsky Island, east-Siberian sea, Russia. Arctic, Antarctic, and Alpine Research 33, 28-35.

Andreev, A.A., Schirrmeister, L., Siegert, Ch., Bobrov, A.A., Demske, D., Seiffert, M., Hubberten, H.W., 2002. Paleoenvironmental changes in northeastern Siberia during the Upper Quaternary:evidence from pollen records of the Bykovsky Peninsula. Polarforschung 70, 13-25.

Andreev, A.A., Tarasov, P.E., Siegert, Ch., Ebel, T., Klimanov, V.A., Bobrov, A.A Melles, M., Derevyagin, A.Yu., Hubberten, H.W., 2003. Vegetation and climate changes on the northern Taymyr, Russia during the Upper Pleistocene and Holocene reconstructed from pollen records. Boreas 32, 484-505.

Andreev, A.A., Tarasov, P.E., Klimanov, V.A., Melles, M., Lisitsyna, O.M., Hubberten, H.-W., 2004a. Vegetation and climate changes around the Lama lake, Taymyr Peninsula, Russia during the Late Pleistocene and Holocene. Quaternary International 122, 69-84.

Andreev, A.A., Tarasov, P.E., Schwamborn, G., Ilyashuk, B.P., Ilyashuk, E.A., Bobrov, A.A., Klimanov, V.A., Rachold, V., Hubberten, H.W., 2004b. Multiproxy Holocene paleoenvironmental records from Nikolay lake, Lena river Delta, arctic Russia. Palaeogeography, Palaeoclimatology, Palaeoecology 209, 197-217.

Andreev, A., Tarasov, P.E., Ilyashuk, B.P., Ilyashuk, E.A., Cremer, H., Hermichen, W.D., Hubberten, H.W., Wischer, F., 2005. Holocene environmental history recorded in the lake Lyadhej-To sediments, Polar Urals, Russia. Palaeogeography Palaeoclimatology Palaeoecology 223, 181-203.

Andreev, A.A., Schirrmeister, L., Tarasov, P.E., Ganopolski, A., Brovkin, V., Siegert, Ch. Wetterich, S., Hubberten, H.W., 2011. Vegetation and climate history in the Laptev Sea region (Arctic Siberia) during Late Quaternary inferred from pollen records. Quaternary Science Reviews 30, 2182-2199.

Baulin, V.V., Danilova, N.S., 1984. Dynamics of late Quaternary permafrost in Siberia In: Velichko, A.A. (Ed.), Late Quaternary Environments of the Soviet Union. University of Minnesota Press, Minneapolis, pp. 69-77.

Bennett, K.D., 1996. Determination of the number of zones in a biostratigraphical sequence. New Phytologist 132, 155-170.

Berglund, B.E., Digerfeldt, G., Engelmark, R., Gaillard, M.J., Karlsson, S., Miller, U., Risberg, J., 1996. Sweden. In: Berglund, B.E., Birks, H.J.B., RalskaJasiewiczowa, M., Wright, H.E. (Eds.), Palaeoecological Events during the Last 15,000 Years. Regional Synthesis of Palaeoecological Studies of Lakes and Mires in Europe. J. Wiley \& Sons, Chichester, pp. 233-280.

Birks, H.H., 1980. Plant fossils in Quaternary lake sediments. Archiv für Hydrobiologie $15,1-60$.

Birks, H.J.B., 1986. Late-Quaternary biotic changes in terrestrial and lacustrine environments, with particular reference to northwest Europe. In: Berglund, B.E. (Ed.), Handbook of Holocene Palaeoecology and Palaeohydrology. J. Wiley \& Sons, Chichester, pp. 3-65.

Birks, H.J.B., 1995. Quantitative palaeoenvironmental reconstructions. In: Maddy, D., Brew, J.S. (Eds.), Statistical Modelling of Quaternary Science Data. Technical Guide 5. Quaternary Research Association, Cambridge, pp. 161-254.

Birks, H.J.B., 1998. Numerical tools in palaeolimnology - progress, potentialities, and problems. Journal of Paleolimnology 20, 307-332.

Birks, H.J.B., Gordon, A.D., 1985. Numerical Methods in Quaternary Pollen Analysis. Academic Press, London.

Birks, H.J.B., Line, J.M., Juggins, S., Stevenson, A.C., ter Braak, C.J.F., 1990. Diatoms and $\mathrm{pH}$ reconstruction. Philosophical Transactions of the Royal Society of London, Series B 327, 263-278.

Biskaborn, B., Herzschuh, U., Bolshiyanov, D., Savelieva, L., Diekmann, B., 2012. Environmental variability in northeastern Siberia during the last $\sim 13,300 \mathrm{yr}$ inferred from lake diatoms and sediment-geochemical parameters. Palaeogeography Palaeoclimatology Palaeoecology 329-330, 22-36.

Brodersen, P.K., Lindegaard, C., 1999. Mass occurrence and sporadic distribution of Corynocera ambigua Zetterstedt (Diptera, Chironomidae) in Danish lakes. Neoand palaeolimnological records. Journal of Paleolimnology 22, 41-52.

Brodin, Y.W., 1986. The postglacial history of lake Flarken, southern Sweden, interpreted from subfossil insect remains. Internationale Revue der gesamten Hydrobiologie 71, 371-432.

Brooks, S.J., Birks, H.J.B., 2000. Chironomid-inferred late-glacial and early-Holocene mean July air temperatures for Krắkenes Lake, western Norway. Journal of Paleolimnology 23, 77-89. 
Brooks, S.J., Birks, H.J.B., 2001. Chironomid-inferred air temperatures from lateglacial and Holocene sites in north-west Europe: progress and problems. Quaternary Science Reviews 20, 1723-1741.

Brooks, S.J., Langdon, P.G., Heiri, O., 2007. Using and Identifying Chironomid Larvae in Palaeoecology. QRA Technical Guide $\mathcal{N}$ o 10. Quaternary Research Association, London.

Brundin, L., 1956. Zur Systematik der Orthocladiinae (Dipt., Chironomidae). Report of the institute of freshwater research. Drottningholm 37, 5-185.

Coope, G.R., 1986. Coleoptera analysis. In: Berglund, B.E. (Ed.), Handbook of Holocene Palaeoecology and Palaeohydrology. J. Wiley \& Sons, Chichester, pp. 703-713.

Cranston, P.S., Oliver, D.R., Saether, O.A., 1983. The larvae of the Orthocladiinae (Diptera: Chironomidae) of the Holarctic region. Keys and diagnoses. Entomologica Scandinavica Supplement 19, 149-291.

Danzeglocke, U., Jöris, O., Weninger, B., 2010. CalPal-2007. Available at: http://www. calpal-online.de (accessed 08.11.11.).

Davis, B.A.S., Brewer, S., Stevenson, A.C., Guiot, J., 2003. The temperature of Europe during the Holocene reconstructed from pollen data. Quaternary Science Reviews 22, 1701-1716.

Dean, W.E., 1999. The carbon cycle and biogeochemical dynamics in lake sediments. Journal of Paleolimnology 21, 375-393.

Digerfeldt, G., 1986. Studies on past lake-level fluctuations. In: Berglund, B.E. (Ed.), Handbook of Holocene Palaeoecology and Palaeohydrology. J. Wiley \& Sons, Chichester, pp. 127-143.

Engels, S., Helmens, K.F., Väliranta, M., Brooks, S.J., Birks, H.J.B., 2010. EarlyWeichselian (MIS 5d and 5c) temperatures and environmental changes in northern Fennoscandia as recorded by chironomids and macroremains at Sokli, northeast Finland. Boreas 39, 689-704.

Forsberg, C., 1965. Ecological and physiological studies of charophytes. Abstracts of Uppsala Dissertations in Science 53, 1-10.

Fradkina, A.F., Alekseev, M.N., Andreev, A.A., Klimanov, V.A., 2005. East Siberia (based on data obtained mainly in central Yakutia). In: Velichko, A.A. Nechaev, V. (Eds.), Cenozoic Climatic and Environmental Changes in Russia. University of Colorado Press, Boulder, pp. 89-103.

Frenzel, B., Pecsi, M., Velichko, A.A., 1992. Atlas of Paleoclimates and Paleoenvironments of the Northern Hemisphere: Late Pleistocene-Holocene. Gustav Fischer Verlag, Stuttgart.

Gavrilova, M.K., 1973. Climate of Central Yakutia (Klimat Centralnoy Yakutii). Yakutian Book Publishers, Yakutsk, 120 pp. (in Russian).

Heiri, O., Lotter, A.F., 2001. Effect of low count sums on quantitative environmental reconstructions: an example using subfossil chironomids. Journal of Paleolimnology 26, 343-350.

Hill, M.O., 1973. Diversity and evenness: a unifying notation and its consequences Ecology 54, 427-432.

Hubberten, H.W., Andreev, A., Astakhov, V.I., Demidov, I., Dowdeswell, J.A., Henriksen, M., Hjort, C., Houmark-Nielsen, M., Jakobsson, M., Kuzmina, S. Larsen, E., Lunkka, J.P., Lysa, A., Mangerud, J., Möller, P., Saarnisto, M. Schirmeister, L., Sher, A.V., Siegert, C., Siegert, M., Svendsen, J.I., 2004. The periglacial climate and environment in northern Eurasia during the last Glaciation. Quaternary Science Reviews 23, 1333-1357.

Juggins, S., 2007. C2 Version 1.5 User Guide. Software for Ecological and Palaeoecological Data Analysis and Visualisation. Newcastle University, Newcastle upon Tyne, UK.

Kienast, F., Wetterich, S., Kuzmina, S., Schirrmeister, L., Andreev, A., Tarasov, P. Nazarova, L., Kossler, A., Frolova, L., Kunitsky, V., 2011. Paleontological records prove boreal woodland under dry inland climate at today's Arctic coast in Beringia during the last interglacial. Quaternary Science Reviews 30, 2134 2159.

Klimanov, V.A., 1992. The map of annual mean temperature: Holocene. In: Frenzel, B. Pecsi, M., Velichko, A.A. (Eds.), Atlas of Paleoclimates and Paleoenvironments of the Northern Hemisphere. Gustav Fischer Verlag, Stuttgart, p. 73.

Kornijów, R., Halkiewicz, A., 2007. Are the larvae of Propsilocerus lacustris Kieffer 1923 (Diptera: Chironomidae) favoured by nutrient-rich lakes? Aquatic Insects: International Journal of Freshwater Entomology 29, 187-194.

Koshkarova, V., Koshkarov, A., 2004. Regional signatures of changing landscape and climate of northern Central Siberia in the Holocene. Russian Geology and Geophysics 45, 672-685.

Kremenetski, C.V., 1996. The Late Holocene environmental and climate shift in Russia and surrounding lands. In: Dalfes, H.N., et al. (Eds.), Third Millennium BC Climate Change and Old World Collaps. Berlin, Heidelberg, New York, pp. 351370 .

Kumke, T., Kienel, U., Weckström, J., Korhola, A., Hubberten, H.W., 2004. Inferred Holocene Paleotemperatures from diatoms at lake Lama, central Siberia. Arctic Antarctic, and Alpine Research 36, 624-634.

Kumke, T., Ksenofontova, M., Pestryakova, L., Nazarova, L., Hubberten, H.W., 2007. Limnological characteristics of lakes in the lowlands of Central Yakutia, Russia. Journal of Limnology 66, 40-53.

Larocque, I., 2001. How many chironomid head capsules is enough? A statistical approach to determine sample size for paleoclimatic reconstruction. Palaeogeography Palaeoclimatology Palaeoecology 172, 133-142.

Lotter, A.F., Juggins, S., 1991. POLPROF, TRAN and ZONE: programs for plotting editing and zoning pollen and diatom data. Inqua-Subcommission for the study of the Holocene, Working Group on Data-Handling Methods. Newsletter 6, 4-6.

Lüpfert, H., 2006. Holozäne Klima- und Umweltentwicklung in Zentraljakutien (NESibirien): Hinweise aus Seesedimenten. Geographisches Institut, HumboldtUniversität Berlin, AWI Potsdam, Periglazialforschung.
Mayewski, P.A., Rohling, E.E., Stager, J.C., Karlen, W., Maasch, K.A., Meeker, L.D., Meyerson, E.A., Gasse, F., van Kreveld, S., Holmgren, K., Lee-Thorp, J. Rosqvist, G., Rack, F., Staubwasser, M., Schneider, R.R., Steig, E.J., 2004. Holocene climate variability. Quaternary Research 62, 243-255.

Meyers, P.A., Teranes, J.L., 2001. Sediment organic matter. In: Last, W.M., Smol, J.P. (Eds.), Tracking Environmental Change Using Lake Sediments. Physical and Geochemical Methods, vol. 2, Dordrecht, pp. 239-270.

Moller Pillot, H.K.M., Buskens, R.F.M., 1990. De larven der Nederlandse Chironomidae. Autoecologie en verspreiding. Nederlandse Faunistische Mededelingen $1 c, 1-87$.

Monserud, R.A., Tchebakova, N.M., Denissenko, O.V., 1998. Reconstruction of the mid-Holocene paleoclimate of Siberia using a bioclimatic vegetation model. Palaeogeography, Palaeoclimatology, Palaeoecology 139, 15-36.

Müller, S., Tarasov, P.E., Andreev, A.A., Diekmann, B., 2009. Late Glacial to Holocene environments in the present-day coldest region of the Northern Hemisphere inferred from a pollen record of lake Billyakh, Verkhoyansk Mts, NE Siberia. Climate of the Past 5, 73-84.

Nazarova, L.B., Pestryakova, L.A., Ushnitskaya, L., Hubberten, H.W., 2008. Chironomids (Diptera: Chironomidae) in lakes of central Yakutia and their indicative potential for paleoclimatic research. Contemporary Problems of Ecology 1, 335-345.

Nazarova, L., Herzschuh, U., Wetterich, S., Kumke, T., Pestjakova, L., 2011. Chironomid-based inference models for estimating mean July air temperature and water depth from lakes in Yakutia, northeastern Russia. Journal of Paleolimnology 45, 57-71.

New, M., Lister, D., Hulme, M., Makin, I., 2002. A high-resolution data set of surface climate over global land areas. Climate Research 21, 1-25.

Palagushkina, O.V., Nazarova, L.B., Wetterich, S., Shirrmaister, L., 2012. Diatoms from sediments of water bodies of Siberian Arctic. Siberian Ecological Journal 4.

Pestryakova, L., Herzschuh, U., Wetterich, S., Ulrich, M., 2012. Present-day variability and Holocene dynamics of permafrost-affected lakes in central Yakutia (Eastern Siberia) inferred from diatom records. Quaternary Science Reviews 51, 56-70.

Pielou, E.C., 1966. The measurement of diversity in different types of biological collections. Journal of Theoretical Biology 13, 131-144.

Pisaric, M.F.J., MacDonald, G.M., Velichko, A.A., Cwynar, L.C., 2001. The Lateglacial and Postglacial vegetation history of the northwestern limits of Beringia, based on pollen, stomate and tree stump evidence. Quaternary Science Reviews 20 $(1-3), 235-245$.

Popp, S., Diekmann, B., Meyer, H., Siegert, Ch., Syromyatnikov, I., Hubberten, H.W., 2006. Palaeoclimate Signals as inferred from stable-isotope composition of ground ice in the Verkhoyansk foreland, central Yakutia. Permafrost and Periglacial Processes 17, 119-132.

Quinlan, R., Smol, J.P., 2001. Setting minimum head capsule abundance and taxa deletion criteria in chironomid-based inference models. Journal of Paleolimnology 26, 327-342.

Renssen, H., Seppa, H., Heiri, O., Roche, D., Goosse, H., Fichefet, T., 2009. The spatial and temporal complexity of the Holocene thermal maximum. Nature Geoscience 2, 410-413.

Schirrmeister, L., Grosse, G., Schnelle, M., Fuchs, M., Krbetschek, M., Ulrich, M., Kunitsky, V., Grigoriev, M., Andreev, A., Kienast, F., Meyer, H., Babiy, O., Klimova, I., Bobrov, A., Wetterich, S., Schwamborn, G., 2011. Late Quaternary paleoenvironmental records from the western Lena Delta, arctic Siberia. Palaeogeography, Palaeoclimatology, Palaeoecology 299, 175-196.

Self, A.E., Brooks, S.J., Birks, H.J.B., Nazarova, L., Porinchu, D., Odland, A., Yang, H., Jones, V.J., 2011. The distribution and abundance of chironomids in highlatitude Eurasian lakes with respect to temperature and continentality: development and application of new chironomid-based climate-inference models in northern Russia. Quaternary Science Reviews 30, 1122-1141.

Serebryanny, L., Andreev, A., Malyasova, E., Tarasov, P., Romanenko, F., 1998. Lateglacial and early-Holocene environments of Novaya Zemlya and the Kara sea region of the Russian arctic. Holocene $8,323-330$.

Sladecek, V., 1973. System of water quality from the biological point of view. Archiv fur Hydrobiologie. Beiheft Ergebnisse der Limnologie, Heft 7, 1-218.

Smirnov, N.P. (Ed.), 1993. Theoretical Questions of the Lake Classification (Teoreticheskie voprosy klassifikacii ozer). St. Peterburg, Nauka (in Russian).

Smol, J.P., Wolfe, A.P., Birks, H.J.B., Douglas, M.S.V., Jones, V.J., Korhola, A., Pienitz, R., Rühland, K., Sorvari, S., Antoniades, D., Brooks, S.J., Fallu, M.-A., Hughes, M., Keatley, B., Laing, T., Michelutti, N., Nazarova, L., Nyman, M., Paterson, A.M., Perren, B., Quinlan, R., Rautio, M., Saulnier-Talbot, É., Siitonen, S., Solovieva, N., Weckström, J., 2005. Climate-driven regime shifts in the biological communities of Arctic lakes. Proceedings of the National Academy of Sciences of the United States of America 102, 4397-4402.

Solovieva, N., Jones, V.J., Nazarova, L., Brooks, S.J., Birks, H.J.B., Grytnes, J.A. Appleby, P.G., Kauppila, T., Kondratenok, B., Renberg, I., Ponomarev, V., 2005. Palaeolimnological evidence for recent climate change in lakes from the Northern Urals, Russia. Journal of Palaeolimnology 33, 463-482.

Solovieva, N., Jones, V.J., Birks, H.J.B., Appleby, P.G., Nazarova, L., 2008. Diatom responses to 20th century climate warming in lakes from the northern Urals, Russia. Palaeogeography, Palaeoclimatology, Palaeoecology 259, 96-106.

Tarasov, P.E., Guiot, J., Cheddadi, R., Andreev, A.A., Bezusko, L.G., Blyakharchuk, T.A., Dorofeyuk, N.I., Filimonova, L.V., Volkova, V.S., Zernitskaya, V.P., 1999. Climate in northern Eurasia 6000 years ago reconstructed from pollen data. Earth and Planetary Science Letters 171 (4), 635-645.

Tarasov, P.E., Bezrukova, E.V., Krivonogov, S.K., 2009. Late glacial and Holocene changes in vegetation cover and climate in southern Siberia derived from a $15 \mathrm{kyr}$ long pollen record from Lake Kotokel. Climate of the Past 5, 285-295. 
Tarasov, P., Müller, S., Zech, M., Andreeva, D., Diekmann, B., Leipe, C. Last glacial vegetation reconstructions in the extreme-continental eastern Asia: potentials of pollen and n-alkane biomarker analyses. Quaternary International, in this volume. Teller, J.T., Last, W.M., 1982. Pedogenic zones in postglacial sediment of Lake Manitoba, Canada. Earth Surface and Landforms 7, 367-379.

ter Braak, C.J.F., 1995. Ordination. In: Jongman, R.H.G., ter Braak, C.J.F., van Tongeren, O.F.R. (Eds.), Data Analysis in Community and Landscape Ecology. Cambridge University Press, Cambridge, pp. 69-173. ter Braak, C.J.F., Šmilauer, P., 2002. CANOCO Reference Manual and CanoDraw for Windows User's Guide: Software for Canonical Community Ordination (Version 4.5). Microcomputer Power, Ithaca, NY.

Wetterich, S., Schirrmeister, L., Kholodov, A.L., 2008. The Joint Russian-German Expedition Beringia/Kolyma 2008 During the International Polar Year (IPY) 2007/2008. In: Reports on Polar and Marine Research, vol. 636. Bremerhaven. Wiederholm, T., 1983. Chironomidae of the holarctic region. Keys and diagnoses. Part 1. Larvae. Entomologica Scandinavica (Suppl. 19). 